\title{
LA REGENTA
}

\section{Leopoldo ALAS “CLARÍN” / Rafael RODRÍGUEZ MARÍN (ed.)}

(Barcelona: Castalia Didáctica, 2019, 1245 págs.)

Se trata de la última y, desde luego, más voluminosa entrega (un abultado volumen de 1245 páginas) de la colección Castalia Didáctica, inaugurada en 1983 con la edición de La vida es sueño y que, si no calculo mal, va por 39 títulos, entre obras clásicas y antologías, destinadas todas a estudiantes de Bachillerato y de los primeros cursos de la universidad y a estudiantes extranjeros, pero que, como veremos a propósito de esta edición didáctica de La Regenta, pueden resultar de gran utilidad para el profesorado. Una colección ya ensayada por Rafael Rodríguez Marín, quien en 1986 publicó en ella una excelente antología de Relatos breves de Clarín.

Como todas las obras de la colección, esta edición de La Regenta incluye una cronología del autor y su época, una introducción sobre el autor y su obra, el texto íntegro anotado con llamadas de atención y unos anexos con documentos y juicios críticos, así como orientaciones para el estudio. Pero, con respecto a anteriores ediciones críticas de referencia, lo que sin duda más impacta es la enorme capacidad de Rodríguez Marín para hacer legible, asequible y comprensible un texto escrito para un lector modelo o implícito que, por utilizar las categorías propuestas por Wolfgang Yser, a todas luces tenía un repertorio lingüístico y cultural muy distinto del de un estudiante de bachillerato de hoy.

Este texto es básicamente el establecido por Gonzalo Sobejano en su edición de 1981 para Clásicos Castalia, sin comentarios de crítica genética o textual, pero con ortografía actualizada según las normas de la Real Academia Española. También se ha reproducido el prólogo de Galdós 
a la edición de 1901.

La gran aportación de Rodríguez Marín es, sin duda alguna, el impresionante corpus de notas aclaratorias que acompañan el texto (más de 4000, cuatro veces más que en las ediciones de Sobejano, Oleza o Gómez), destinadas a hacer asequible el repertorio lingüístico y cultural referencial de La Regenta, así como su funcionamiento, al lector modelo de esta edición, teniendo en cuenta su escaso saber lectorial preexistente.

Hoy en día, Rafael Rodríguez Marín es tal vez el que mejor conoce la lengua de los novelistas del Gran Realismo (ahí está su fundamental trabajo de 2005 sobre Metalengua y variación lingüística en la novela de la Restauración decimonónica). Y ha aplicado su ciencia a la lengua de Clarín en La Regenta con toda maestría y pertinencia. Nadie como él para caracterizar las palabras y expresiones (coloquialismos, asturianismos, latinismos, galicismos, extranjerismos, neologismos, vulgarismos, etc.), sus usos en la época y darles el correcto sentido en su contexto.

Con respecto a las demás ediciones, casi no hay palabra o expresión potencialmente un poco oscura que se salve, de manera que el conjunto de las notas lingüísticas de esta edición se puede considerar como un diccionario particular de la lengua de Clarín al que solo le falta el orden alfabético y, además, un diccionario de usos.

Las aclaraciones de Rodríguez Marín no son meras reproducciones de las definiciones del Diccionario de la Real Academia Española (DLE), muy familiar para el lexicógrafo: se trata de verdaderas explicaciones con palabras del autor de las notas. Valga como muestra la nota de la página 1065 para explicar la secuencia con puntales de tolerancia y estribos de paciencia: "sustentándose en la tolerancia como si fuera un puntal —un madero que sostiene un edificio que amenaza ruina-, y en la paciencia, como si fuera un estribo - una pieza de metal donde el jinete apoya el pie_-". O la que explica (pág. 1040) la exclamación de don Víctor en presencia del Magistral, por las once mil... de a caballo: "don Víctor une dos expresiones distintas, interrumpiendo la primera — quizá por respeto al magistral—, por las once mil virgenes, que ya hemos visto (cap. XXIV), y continuándola con otra, con cien mil de a caballo, que se utiliza para expresar indignación". Estas notas ofrecen una verdadera y socorrida ayuda al eliminar posibles contrasentidos como, por ejemplo, en hacer el amor ("galicismo - faire l'amour - ; enamorar, galantear, y no como en nuestros días, practicar el acto sexual”, pág. 232), pero también al señalar 
los usos tópicos de determinados sintagmas (sobre la verde alfombra: "uso tópico — señalado por la letra cursiva - Sobre la hierba”, pág. 1033), o sugerir/aconsejar una lectura en sentido figurado. Y así por el estilo, para centenares de vocablos o sintagmas.

Por supuesto, algún don (o doña) Hermógenes se extrañará de que a un chico/una chica de hoy haga falta explicarle el sentido de era menester (pág. 129), de soplarse los dedos ("para calentárselos", pág. 407), de sintió brasas en las mejillas ("se ruborizó", pág. 224) o de maledicencia (pág. 161), por poner algunos ejemplos; o, al contrario, censurará alguna excepcional ausencia de explicación. Pero la verdad es que, para el primer caso citado, la elección de las palabras difíciles de entender por el lector modelo es materia opinable y mejor es pecar por exceso y suponer al lector muy ignorante de la lengua de Clarín, pero también de los registros menos corrientes de la lengua española. En cualquier caso, cualquier ayuda sistemática viene mejor que una aleatoria y frustrante arbitrariedad. Además, la mera presencia de una nota le hace a uno caer en la cuenta de que ha podido leer una y otra vez La Regenta sin saber exactamente lo que significa el poder diaforético de un alcohol (la "capacidad de hacer sudar", pág. 851), lo que significa Mesía había nacido para algo más que cabeza de ratón ("alusión — en sentido contrario — al refrán que dice: 'Más vale ser cabeza de ratón que cola de león', con el que se da a entender que es mejor desempeñar un papel principal en una acción de menos importancia que desempeñar un papel secundario en una acción principal”, pág. 710), ni lo que supone gastar unas zapatillas suizas ("zapatillas con suela de material suave, lo que les hacía muy silenciosas", pág. 871).

Además, al insistir en el uso de la lengua como elemento caracterizador, permiten las notas percibir cómo las representaciones verbales adquieren "personalidad narrativa" (pág. 620), hasta llegar a ser, como escribe Rodríguez Marín, un verdadero "arte de la representación verbal de los personajes". También permiten analizar la variación lingüística, discriminando entre la lengua estándar y la que no lo es, por pertenecer a la lengua del periodismo practicado con mucha intensidad por Clarín, como se sabe, o lo que le pertenece en propiedad. De igual modo, las notas permiten medir las distancias existentes entre el diccionario común y el diccionario propio de Clarín - algo que merecería un estudio sistemático- $\mathrm{y}$, por supuesto, captar el frecuente valor irónico que cobran unas palabras o expresiones aparentemente comunes; y que, ya que en las 
ediciones críticas aún no se ha generalizado el punto de ironía imaginado por Alcanter de Brahm, Rodríguez Marín se cuida de sugerir más que de señalar, con infinita discreción y eficacia.

Para el segundo caso antes mencionado - los posibles fallos-, hay que esforzarse mucho para encontrar estos excepcionales lunares. Tal vez alguna explicación demasiado marcada por la ideología de la época, como explicar que los cementerios civiles estaban "destinados a enterrar a quienes morían en pecado [sin comillas] (ateos, masones, suicidas, etc.)" (pág. 876). Y si, en un caso como el de la enigmática formulación del narrador casta por vigor del temperamento se explicita y traduce con otras palabras que no quitan el sabor de la prudente formulación clariniana ("que se abstiene de placeres sexuales por la fortaleza de su carácter”, pág. 237), tal vez sea preferible dejar al lector que imagine los nombres afeminados aunque fuesen masculinos, que estaban grabados como si fuesen de fuego en la memoria de Visita (pág. 345).

Refiriéndonos ahora al tratamiento del repertorio cultural, podemos decir que, si Rodríguez Marín "sabe diccionario", como decía Clarín, también tiene un saber enciclopédico. Este saber le permite al lector enterarse — son ejemplos — de lo que significa pesar quintales (pág. 110) o de lo que es un cuadro disolvente ("sistema precursor del cine"), pero también asociar el niño perdido (pág. 565) con un pasaje evangélico (Lucas, 2, 41-52), Alancardan o san Cardan, o san Diablo, como dice don Frutos, con "Allan Kardec, pseudónimo de Hyppolite Léon Rivail (1804-1869), pedagogo francés que dedicó su vida al espiritismo [y] fue muy popular en España, donde se tradujeron varias de sus obras" (pág. 761), y entender por qué le gustaba mucho al indiano Páez el estilo cortado del Evangelio del pueblo de Henao y Muñoz (el único libro religioso que trajo de América), ya que se trata de "una obra de intención educativa [no religiosa; de ahí la ironía] escrita en capítulos breves a base de párrafos cortos" (pág. 497). Ni que decir tiene que quedan explicitadas las infinitas intertextualidades, implícitas, como en la zarza de la loma que se movía (pág. 214), relacionada con el pasaje de la Biblia "en que Dios se presenta ante Moisés como una zarza ardiente que no se consume", o explícitas, como en el caso de $O$ el cielo o el suelo [todo no puede ser], obra de Eugenio Sellés, estrenada en 1880, que, observa Rodríguez Marín, "no tiene nada que ver con la intención del enunciado en La Regenta" (pág. 613); o como en el caso de la copla cantada por Joaquinito Orgaz (pág. 
793), cuya letra, aclara el editor, era la misma que cantaba "el actor Ricardo Zamacois en una revistilla de 1874", una referencia cultural compartida o no por los lectores y que, gracias a la nota, se vuelve compartible. Quien no tenga la cultura mitológica suficiente le agradecerá al anotador que le aclare el apelativo de Pílades cinegético aplicado a Frígilis: "amigo inseparable (como, en la mitología griega, Pílades y Orestes) y compañero en la caza" (pág. 177). Se puede observar, incluso, cómo las referencias a la actualidad pueden servir para dar cuenta de situaciones o realidades de finales del siglo XIX, como cuando se explica que la butaca en la que Bismarck recuerda haber visto sentao al Papa, es "la silla gestatoria, en nuestros días [...] sustituida por el papamóvil" (pág. 93), que el Ministerio de Gracia y Justicia es "el actual Ministerio de Justicia" (pág. 140) o que la Montaña es "la denominación tradicional de la actual comunidad autónoma de Cantabria" (pág. 594). Cuando, ante el espectáculo de señores y colonos confundidos en el Vivero, un enternecido Víctor exclama Si se pudiera realizar la igualdad y fraternidad, se recuerda que "el lema de la Revolución francesa - y el de la actual República francesa - era 'libertad, igualdad y fraternidad"' (pág. 1063), dejando al lector la responsabilidad de interpretar la exclamación del exregente.

Hasta advierte Rodríguez Marín alguna equivocación de Clarín, como sucede en el momento en que el narrador dice que Frígilis ve aparecer a Petra con el cabello suelto, en chambra y mal tapada son un mantón viejo del ama. Parecía la aurora de las doradas guedejas, cuando "la Aurora, deidad que en la mitología romana personifica el amanecer, suele ser representada con un manto o velo amarillo, pero no con cabellos (guedejas) rubios" (pág. 689).

La verdad es que da envidia tanto saber para cuya construcción el editor didáctico - lo deja claro en la página 69- ha podido tener en cuenta el preexistente en las ediciones de Sobejano, Oleza y Gómez.

Pero lo que más admira, si cabe, es que ese saber excluye la innecesaria erudición (una excepción, pág. 525) y, por supuesto, cualquier pedantería. Rodríguez Marín no pretende imponerse al lector; no se siente una potencia, la que pudiera otorgarle el estatuto de teniente de autor o autor-bis, que tiene a veces el editor crítico. En tal sentido, llama la atención que en esta edición didáctica haya poquísimas notas interpretativas: suelen limitarse a sugerir que tal o cual palabra o expresión se ha de leer en clave irónica (cf. págs. 119, 126, 230, 326, 836, por ejemplo) o interpretarse en 
sentido figurado ("aquí debe interpretarse en sentido figurado"; "entiéndase con la imaginación").

Al suministrarle ese consaber, el editor ayuda al lector a enfrentarse con aquel "desafío al lector" tan característico de Clarín; le da la halagüeña sensación de que es inteligente, o sea, un verdadero cooperador en la interpretación de la novela.

Esta misma sensación se desprende de la consulta de las 412 notas contextuales que en el texto vienen con llamadas entre corchetes y que, como en las ediciones de Crítica, se encuentran en un apéndice al final (págs. 1179-1206).

Allí encontrará el lector útiles informaciones sobre dónde va desarrollándose la acción (con muchas correspondencias con Oviedo y personas/modelos reales), sobre los recursos narrativos y estilísticos empleados por Clarín, la reflexividad, la impersonalidad de un narrador que "no suele entrometerse en la narración", el valor de la cursiva estudiada por José Carlos Mainer en 2005, e incluso las técnicas cinematográficas intuidas por José Manuel González Herrán, ya en 1987.

Permite, en su caso, llamar la atención sobre las rupturas y cambios en la línea narrativa, como al principio del capítulo XI, cuando "la potente lupa del narrador se vuelve ahora hacia el magistral", sobre las imágenes degradadoras o sobre el carácter "atrevido para la época" de la escena en la que Teresina, casi tendida de bruces sobre la cama, deja ver al Magistral más de media pantorrilla y mucha tela blanca: "la de las enaguas y fajas interiores, cuya vista era entonces, como la de los tobillos y las pantorrillas, claramente erótica" (pág. 427). Y permite también señalar tanto la fijación de Clarín por el mal tiempo (pero también por los tópicos) como el carácter "neurótico" de Ana Ozores o la ideología antifeminista de la época.

Esta Summa didáctica — didacrítica, se podría decir- es una verdadera obra articulada al texto; una "obra de notas", en la que el autor acompaña al lector con recursos expositivo-narrativos ("como adelante veremos", "como sabemos", "como hemos visto") propios de un bondadoso maestro. Nada, pues, de esos "ladrillos sueltos al lado del edificio", censurados por Jorge Guillén. Se trata de notas coherentes, al servicio del texto y respetuosas con el lector. Y, además, se puede observar que las diminutas y discretas llamadas de las notas permiten ignorarlas y, por ende, prescindir de las explicaciones que contienen y solo utilizarlas cuando hacen falta, que será a menudo, para comprobar la correcta 
comprensión, incluso cuando de profesores se trata. Esto, por supuesto, no ha de librarnos de acudir a un diccionario general de la lengua para buscar más sentidos y enriquecer nuestro conocimiento de la lengua, práctica de autodidaxia aún muy aconsejable, incluso en ámbitos académicos.

De los demás componentes de reglamento en la colección Castalia Didáctica se dirá que, en la sección icónica de ilustraciones que viene después de una precisa cronología del autor y su época, el editor comercial ha privilegiado la reproducción de fotogramas de la adaptación cinematográfica de Méndez Leite (pág. 28), más actuales que las ilustraciones originales de la primera edición de Arte y Letras por Joan Llimona y Francisco Gómez Soler. También podrá decirse que la bibliografía que sigue a una introducción clásica, es decir, muy adaptada al público escolar o universitario, padece un poco de lo que ha tardado el editor en publicar este trabajo de años y hace muchos años acabado (se cita, sin embargo, con toda razón, la biografía de Leopoldo Alas por Yvan Lissorgues de 2007) y que en los anexos se reproducen algunos documentos y juicios críticos que hacen al caso.

En cuanto a las “orientaciones para el estudio" (págs. 1209-1234), también de reglamento son las clásicas que consisten en "buscar", "rastrear", "localizar", "identificar", "clasificar", “explicar", "analizar", "completar", "ampliar información”, y se aplican a la España del siglo XIX, la ficción y la realidad en la novela (tal vez no sea de tanta utilidad pedagógica la situación de los lugares de la novela en la Oviedo actual), los personajes, la religión y el clero, el sentimiento de la naturaleza, el lenguaje, etc. Por cierto, muy fecundo será para un aprendiz de filólogo reconstruir un retrato básico (prosopografía y etopeya) de Ana Ozores, Fermín de Pas, Víctor Quintanar y Álvaro Mesía; y bastante original y novedoso interrogarse sobre la causticidad lingüística o "un recurso singular: el empleo de la letra cursiva", muy especialmente cuando delata una intención irónica característica de una estética clariniana tan convincentemente delineada por Carole Fillière en L'esthétique ironique de Leopoldo Alas Clarín (Madrid: Casa de Velázquez, 2011).

Sobre lo que pertenece al editor comercial, además de lo ya señalado, se podrá echar en falta en tan larga novela la ausencia en los encabezamientos de cada página de la mención del capítulo en curso, y lamentar la supresión, en el capítulo XXVII (pág. 1031), después del famoso y eufemístico Hablaron, de un muy elocuente blanco tipográfico 
presente en la primera edición y en las siguientes. Se dará por bueno el retrato de cubierta Retrato de dama en azul, de Raimundo de Madrazo, pintado entre 1897 y 1905 (cada clarinista tiene su propia representación gráfica de Ana Ozores), pero no tanto el muy reductor y pedestre resumen que se hace de la obra en la cuarta de cubierta, más propio de una novela de folletín que de una obra perteneciente al canon literario universal.

Algún crítico de ediciones críticas, partidario de la no anotación de las obras clásicas, opinará que esta edición es como una Regenta para vagos, pero, secreta o inconfesadamente, seguro que tampoco dejará de acudir a la subsidiaria, pero ilustrada, sabiduría de Rodríguez Marín. No digamos los aprendices de filólogos y también los más curtidos o veteranos.

Enseñar al que no sabe es obra de misericordia y, como hermano mayor, más compañero que maestro o superlector, Rodríguez Marín ayuda a una lectura más fructífera de La Regenta (obra con fama de difícil), sin imponer su propia lectura, sin empecer la libertad del lector.

La edición didáctica de La Regenta ofrece, pues, una lectura más acompañada que guiada, haciendo que el texto hable al lector sin rodrigón ni corsé pedagógico. Y de resultas — algo muy de agradecer - le hace al lector más inteligente.

Jean-François Botrel Université Rennes 2 